\title{
Influence of flower functionality and pollination system on the pollen size-pistil length relationship
}

\author{
Verónica Andrea Fernández, Leonardo Galetto*, Julia Astegiano \\ Instituto Multidisciplinario de Biología Vegetal (UNC-CONICET), cc 495, 5000, Córdoba, Argentina
}

Received 15 October 2008; accepted 15 January 2009

\begin{abstract}
Twenty-five biotically pollinated plants of the Chaco Serrano Forest (Córdoba, Argentina) were studied in order to analyze whether 'flower functionality' is related to the relationship between pollen size and pistil length. Because flower functionality may act on the respective mean values of pollen size and pistil length rather than on intraspecific variation in these traits, we expected (1) a high positive correlation between pollen size and pistil length in a set of sympatric species, independent of their degree of pollination specialization or generalization; and (2) no interspecific correlation between the coefficients of variation $(\mathrm{CVs})$ of those traits. On the other hand, on the assumption that pollinators are influencing the variation in floral traits (e.g. in pistil length) we expected lower mean phenotypic variation of pollen size and pistil length in pollination-specialist plants than in pollination-generalist ones. A positive correlation between pollen size and pistil length was found for the set of species, but not between the CVs of these traits. This trend was maintained when pollination-specialist plants were analyzed separately, but no statistical significance was obtained for the correlation in pollination-generalist plants. Contrary to our expectations, pollinationspecialist plants did not show less mean intraspecific variation in floral traits than pollination-generalist plants. Therefore, the relationship between pollen size and pistil length among species suggests that the pollination system may be of less importance as a selective force than flower functionality.
\end{abstract}

(C) 2009 Gesellschaft für Biologische Systematik. Published by Elsevier GmbH. All rights reserved.

Keywords: Coefficient of variation; Functional correlation; Pistil length; Pollen size; Pollination systems; Pollinators

\section{Introduction}

The study of the factors influencing the adjustments of floral traits among species constitutes a central issue in comparative plant ecology (e.g. Baker and Baker 1979; Armbruster et al. 1995; Armbruster 1996; Herrera 1996; Cresswell 1998; Fenster et al. 2004). The variation observed for a given floral trait in a sample of unrelated

\footnotetext{
*Corresponding author. Tel.: + 543514332104 ; fax: +543514332104

E-mail address: leo@imbiv.unc.edu.ar (L. Galetto).
}

species can be linked to its function. For instance, many floral traits are related to the pollination and fertilization processes, i.e. floral traits can be adjusted by selection to ensure pollen transfer, the subsequent growth of pollen tubes through the pistil, and finally ovule fertilization. Thus, floral traits act as components of a 'floral integrated design', and therefore their size and variability can be related to the pollination process, i.e. they cannot vary independently (Sarkissian and Harder 2001; Herrera et al. 2002).

Pollen grain size and pistil length are traits that may be 'functionally adjusted' because they are related to the 
pollination and fertilization processes. Since the pollen grain contains many of the necessary resources for pollen tube growth, e.g. specific enzymes (Roulston et al. 2000; studies reviewed in Torres 2000), evolutionary changes in pistil length should necessarily imply changes in pollen size. Otherwise, pollen tubes would simply fail to reach the ovules (Aguilar et al. 2002), and the functional integrity of the system would not be maintained (Plitmann and Levin 1983). Therefore, a positive correlation between pollen size and pistil length should result when a sample of unrelated species from the same community is examined, independent of the degree of pollination specialization or generalization of those species. Although many studies have addressed the relationship between pollen size and pistil length, generally they have considered taxonomically related species (e.g. Williams and Rouse 1990; Harder 1998; Torres 2000; Aguilar et al. 2002; Yang and Guo 2004; López et al. 2005). There has not been any study of the pollen size-pistil length relationship in plants from the same community belonging to several species in different genera and families, nor of trends of intraspecific variation in these floral traits.

In addition to the role of functionality, ecological attributes can play an important role in determining differences among species in floral-trait variation. In biotically pollinated plants, the pollinators can influence the amount of variation in floral traits (e.g. Fenster 1991; Proctor et al. 1996; Cresswell 1998; Morales 1999; Bradshaw and Schemske 2003). Pollinators are thought to have the motive (energy and nutrition) and the means (via pollen transfer) to effect selection on some floral features of their host plants (Galen 1999). If pollinators influence the options viable to floral morphologies, they can be a major factor in the intraspecific phenotypic variation of floral traits. In this sense, pollinationspecialist plants interacting with a less diverse fauna of pollinators are more likely to experience strong directional selection on floral traits than pollinationgeneralist species (Herrera 1988; Nilsson 1988; Galen 1999; Johnson and Steiner 2000). As selection on particular floral traits may take effect within just a few plant generations (e.g. Proctor et al. 1996; Galen 1999; Schemske and Bradshaw 1999; Bradshaw and Schemske 2003; Temeles and Kress 2003), it is reasonable to expect that plants with pollination-specialist systems show less phenotypic intraspecific variation in their floral traits (e.g. in pistil length) than pollination-generalist species (Fenster 1991; Morales 1999). Therefore, whether a species interacts with one or several functional groups of pollinators may determine the amount of variation in floral traits (e.g. Bradshaw and Schemske 2003; Fenster et al. 2004). As a consequence, we expect to find that pollination-specialist species show less mean intraspecific variation in both pollen size and pistil length than pollination-generalist ones.
The present study examines a diverse sample of biotically pollinated, sympatric species in the Chaco Serrano Forest (Córdoba, Argentina), to evaluate whether the correlation between pollen size and pistil length is related to 'flower functionality'. We expected to find (1) a high, significant positive correlation between pollen size and pistil length for the set of 25 sympatric species, independent of their degree of pollination specialization or generalization, and (2) no correlation among the coefficients of variation of those traits. In addition, we explore the influence of pollination systems on intraspecific variation in pollen size and pistil length by comparing the latter between pollination-specialist and -generalist species. We expected to find lower mean values for phenotypic variation in pollen size and pistil length within the former group.

\section{Material and methods}

\section{Study area and species}

The study was conducted with species growing in a Chaco Serrano Forest community. The study site (c. 10 ha) is located within a continuous forest $(>500$ ha) on the eastern slope of the Sierras Chicas (Argentina, Córdoba Province, Dept. Santa María; $31^{\circ} 44^{\prime} \mathrm{S}$, $64^{\circ} 26^{\prime} \mathrm{W}$ ) at $650 \mathrm{~m}$ above sea level. The Chaco Serrano is a xerophytic forest with the natural vegetation including small trees, thorn shrubs, cacti, herbs, as well as epiphytes and vines (Cabrera 1994). Mean annual precipitation is c. $800 \mathrm{~mm}$, falling almost entirely during the spring-summer season. For a complete description, see Luti et al. (1979).

A sample of 25 biotically pollinated plant species representing 25 genera and 14 families was selected. Phylogenetic constraints may be important to explain the variation in some characters. However, because no genus or family was over-represented in our taxon sampling, no analysis of phylogenetic constraints was performed. Although some species can produce fruits by spontaneous self-pollination, natural fruit set strongly depends on pollinators (Morales and Galetto 2003). Those species bloom between September and February (Galetto, unpublished data) and they all have hermaphrodite flowers. We chose species so that each allowed us to sample at least five reproductive adult individuals of comparable size. The species examined are listed in Table 1.

Fieldwork was carried out between September 1998 and February 1999, during the spring-summer flowering season in the southern hemisphere. Data were obtained from mature buds and fully opened flowers, which had been taken randomly from five individuals per species. Buds and flowers were preserved in $70 \%$ ethanol. 
Table 1. Pollen size and pistil length (mean \pm standard deviation; $C V=$ coefficient of variation) for 25 species from a community in the Chaco Serrano Forest divided in two pollination categories as explained in the text.

\begin{tabular}{|c|c|c|c|c|c|}
\hline Family & Species & $\begin{array}{l}\text { Pollen grain } \\
\text { volume }\left(\mu \mathrm{m}^{3}\right)\end{array}$ & $\begin{array}{l}\text { Pistil length } \\
(\mathrm{mm})\end{array}$ & $\begin{array}{l}\text { Pollination } \\
\text { system }\end{array}$ & Pollinator functional groups \\
\hline \multirow[t]{2}{*}{ Apocynaceae } & Ambliopetalum coccineum (Griseb.) Malme & $\begin{array}{l}53,809 \pm 20,796 \\
\mathrm{CV}=0.39\end{array}$ & $\begin{array}{l}5.4 \pm 0.4 \\
\mathrm{CV}=0.08\end{array}$ & specialist & diurnal Lepidoptera (Nymphalidae) \\
\hline & Philibertia gilliesii Hook. and Arn. & $\begin{array}{l}161,680 \pm 34,620 \\
\mathrm{CV}=0.21\end{array}$ & $\begin{array}{l}4.2 \pm 0.3 \\
\mathrm{CV}=0.08\end{array}$ & generalist & $\begin{array}{l}\text { long-tongued bees (Apidae); other Hymenotera (Vespidae); } \\
\text { Diptera (Muscidae, Tachinidae) }\end{array}$ \\
\hline \multirow[t]{2}{*}{ Bignoniaceae } & Dolichandra cynanchoides Cham. & $\begin{array}{l}44,352 \pm 36,641 \\
C V=0.83\end{array}$ & $\begin{array}{l}62.4 \pm 3.6 \\
C V=0.06\end{array}$ & specialist & birds (Trochilidae, hummingbirds) \\
\hline & Pithecoctenium cynanchoides DC. & $\begin{array}{l}52,481 \pm 14,154 \\
\mathrm{CV}=0.27\end{array}$ & $\begin{array}{l}27.1 \pm 3.4 \\
\mathrm{CV}=0.13\end{array}$ & specialist & long-tongued bees (Apidae) \\
\hline \multirow[t]{2}{*}{ Convolvulaceae } & Evolvulus sericeus $\mathrm{Sw}$. & $\begin{array}{l}29,679 \pm 2,925 \\
C V=0.10\end{array}$ & $\begin{array}{l}14 \pm 0.9 \\
C V=0.07\end{array}$ & generalist & $\begin{array}{l}\text { diurnal Lepidoptera (Hesperidae, Nymphalidae); } \\
\text { short-tongued bees (Halictidae) }\end{array}$ \\
\hline & Ipomoea hieronymi (Kuntze) O’Donnell & $\begin{array}{l}231,706 \pm 35,259 \\
\mathrm{CV}=0.15\end{array}$ & $\begin{array}{l}27.1 \pm 1.6 \\
\mathrm{CV}=0.06\end{array}$ & specialist & long-tongued bees (Anthophoridae) \\
\hline \multirow[t]{3}{*}{ Fabaceae } & Acacia praecox Griseb. & $\begin{array}{l}2,054 \pm 507 \\
\mathrm{CV}=0.25\end{array}$ & $\begin{array}{l}6.8 \pm 0.6 \\
\mathrm{CV}=0.09\end{array}$ & generalist & $\begin{array}{l}\text { long-tongued bees (Apidae, Anthophoridae); } \\
\text { other Hymenoptera (Vespidae); Diptera (Muscidae, Tachinidae); } \\
\text { diurnal Lepidoptera (Nymphalidae); Coleoptera (Melyridae) }\end{array}$ \\
\hline & Adesmia muricata (Jacq.) DC. & $\begin{array}{l}2,031 \pm 306 \\
\mathrm{CV}=0.15\end{array}$ & $\begin{array}{l}9.9 \pm 0.9 \\
\mathrm{CV}=0.09\end{array}$ & specialist & long-tongued bees (Apidae, Anthophoridae) \\
\hline & Rhynchosia edulis Griseb. & $\begin{array}{l}13,442 \pm 1,154 \\
\mathrm{CV}=0.09\end{array}$ & $\begin{array}{l}8.9 \pm 0.7 \\
\mathrm{CV}=0.08\end{array}$ & generalist & $\begin{array}{l}\text { long-tongued bees (Anthophoridae); Diptera (Muscidae); } \\
\text { Coleoptera (Curculionidae) }\end{array}$ \\
\hline \multirow[t]{2}{*}{ Lamiaceae } & Leonurus sibiricus $\mathrm{L}$. & $\begin{array}{l}3,190 \pm 806 \\
C V=0.25\end{array}$ & $\begin{array}{l}8.7 \pm 1.3 \\
\mathrm{CV}=0.15\end{array}$ & specialist & long-tongued bees (Apidae, Anthophoridae) \\
\hline & Hyptis mutabilis (Rich.) Briq. & $\begin{array}{l}7,938 \pm 1,851 \\
\mathrm{CV}=0.23\end{array}$ & $\begin{array}{l}4.8 \pm 0.4 \\
\mathrm{CV}=0.09\end{array}$ & generalist & $\begin{array}{l}\text { long-tongued bees (Apidae, Anthophoridae); Diptera (Bombilidae); } \\
\text { diurnal Lepidoptera (Nymphalidae) }\end{array}$ \\
\hline Alliaceae & Nothoscordum gracile (Dryand. ex Aiton) Stearn & $\begin{array}{l}8,338 \pm 1,580 \\
C V=0.19\end{array}$ & $\begin{array}{l}6.3 \pm 1.1 \\
\mathrm{CV}=0.17\end{array}$ & generalist & long-tongued bees (Apidae); diurnal Lepidoptera (Pieridae) \\
\hline Loasaceae & Mentzelia albescens (Gillies ex Arn.) Griseb. & $\begin{array}{l}6,287 \pm 1,684 \\
\mathrm{CV}=0.27\end{array}$ & $\begin{array}{l}20.1 \pm 1.2 \\
C V=0.06\end{array}$ & specialist & long-tongued bees (Apidae, Anthophoridae) \\
\hline Lythraceae & Heimia salicifolia (Kunth) Link & $\begin{array}{l}2,888 \pm 792 \\
\mathrm{CV}=0.27\end{array}$ & $\begin{array}{l}13.9 \pm 1.0 \\
C V=0.07\end{array}$ & specialist & long-tongued bees (Apidae, Anthophoridae) \\
\hline Malvaceae & Sphaeralcea cordobensis Krapov. & $\begin{array}{l}23,807 \pm 3,088 \\
\mathrm{CV}=0.13\end{array}$ & $\begin{array}{l}7.3 \pm 0.8 \\
C V=0.10\end{array}$ & generalist & $\begin{array}{l}\text { long-tongued bees (Apidae, Anthophoridae); } \\
\text { other Hymenoptera (Vespidae); Diptera (Muscidae, Bombyliidae); } \\
\text { diurnal Lepidoptera (Hesperidae, Lycaenidae) }\end{array}$ \\
\hline
\end{tabular}


Table 1. (continued)

\begin{tabular}{|c|c|c|c|c|c|}
\hline Family & Species & $\begin{array}{l}\text { Pollen grain } \\
\text { volume }\left(\mu \mathrm{m}^{3}\right)\end{array}$ & $\begin{array}{l}\text { Pistil length } \\
(\mathrm{mm})\end{array}$ & $\begin{array}{l}\text { Pollination } \\
\text { system }\end{array}$ & Pollinator functional groups \\
\hline Onagraceae & Oenothera affinis Cambess & $\begin{array}{l}573,839 \pm 93,065 \\
C V=0.16\end{array}$ & $\begin{array}{l}158.7 \pm 20.6 \\
C V=0.13\end{array}$ & specialist & nocturnal Lepidoptera (Sphingidae) \\
\hline Passifloraceae & Passiflora caerulea $\mathrm{L}$. & $\begin{array}{l}70,997 \pm 13,292 \\
\mathrm{CV}=0.19\end{array}$ & $\begin{array}{l}19.1 \pm 0.8 \\
C V=0.04\end{array}$ & specialist & long-tongued bees (Apidae, Anthophoridae) \\
\hline Rubiaceae & Borreria densiflora DC. & $\begin{array}{l}2,825 \pm 415 \\
C V=0.15\end{array}$ & $\begin{array}{l}4.6 \pm 0.7 \\
C V=0.15\end{array}$ & generalist & $\begin{array}{l}\text { long-tongued bees (Apidae); other Hymenoptera (Vespidae); } \\
\text { Diptera (Bombyiilidae, Tachinidae, Muscidae); } \\
\text { diurnal Lepidoptera (Hesperidae, Nymphalidae); } \\
\text { Coleoptera (Melyridae) }\end{array}$ \\
\hline \multirow[t]{4}{*}{ Solanaceae } & Cestrum parqui L’Hér. & $\begin{array}{l}10,228 \pm 2,651 \\
\mathrm{CV}=0.26\end{array}$ & $\begin{array}{l}19.3 \pm 1.6 \\
C V=0.08\end{array}$ & specialist & nocturnal Lepidoptera (Sphingidae) \\
\hline & Nicotiana longiflora Cavanilles & $\begin{array}{l}9,412 \pm 1,521 \\
\mathrm{CV}=0.16\end{array}$ & $\begin{array}{l}88.5 \pm 7.9 \\
\mathrm{CV}=0.09\end{array}$ & specialist & nocturnal Lepidoptera (Sphingidae) \\
\hline & Salpichroa origanifolia (Lam.) Baill. & $\begin{array}{l}4,209 \pm 855 \\
C V=0.20\end{array}$ & $\begin{array}{l}8.9 \pm 0.7 \\
\mathrm{CV}=0.07\end{array}$ & specialist & long-tongued bees (Anthophoridae) \\
\hline & Solanum kurtzianum Bitter \& Wittm. & $\begin{array}{l}1,360 \pm 295 \\
C V=0.21\end{array}$ & $\begin{array}{l}11.1 \pm 1.3 \\
\mathrm{CV}=0.11\end{array}$ & specialist & long-tongued bees (Anthophoridae) \\
\hline \multirow[t]{3}{*}{ Verbenaceae } & Glandularia laciniata $(\mathrm{L})$ Schnack \& Covas & $\begin{array}{l}18,605 \pm 2,776 \\
\mathrm{CV}=0.15\end{array}$ & $\begin{array}{l}8.9 \pm 0.6 \\
\mathrm{CV}=0.07\end{array}$ & specialist & Lepidoptera (Nymphalidae, Hesperidae) \\
\hline & Lantana grisebachii Seckt. & $\begin{array}{l}11,285 \pm 2,747 \\
C V=0.24\end{array}$ & $\begin{array}{l}1.5 \pm 0.1 \\
\mathrm{CV}=0.08\end{array}$ & generalist & $\begin{array}{l}\text { long-tongued bees (Apidae); other Hymenoptera (Vespidae); } \\
\text { Lepidoptera (Pieridae) }\end{array}$ \\
\hline & Lippia junelliana (Moldenke) Tronc. & $\begin{array}{l}437 \pm 92 \\
\mathrm{CV}=0.21\end{array}$ & $\begin{array}{l}2.4 \pm 0.4 \\
\mathrm{CV}=0.16\end{array}$ & generalist & $\begin{array}{l}\text { long-tongued bees (Apidae); } \\
\text { Lepidoptera (Hesperidae, Nymphalidae) }\end{array}$ \\
\hline
\end{tabular}




\section{Pollen grain size and pistil length}

Pollen size was obtained from ten pollen grains of five different flowers (one undehisced anther per flower) of each individual plant. Anthers were dissected under a stereo microscope, and pollen content was removed. Then, pollen grains were stained with aniline blue. The respective lengths along the equatorial and polar axes were measured with the aid of an ocular micrometer (400x) on a Zeiss Axiolab light microscope. The exine was excluded from pollen size calculations because it does not contribute to pollen tube formation. Abnormal grains were not considered (Covas and Schnack 1945). Pollen grain size, i.e. pollen volume, was calculated as $\pi \mathrm{PE}^{2} / 6$ (cf. Harder 1998), where $\mathrm{P}=$ polar axis diameter, and $\mathrm{E}=$ equatorial axis diameter.

Pistil length was considered as the estimated maximum distance a pollen tube must grow to fertilize an ovule. Pistil length values for each species were obtained from five individuals (from a minimum of five flowers per plant) with a digital caliper (resolution $=0.01 \mathrm{~mm}$ ) and the aid of a Zeiss Stemi SV 6 magnifying glass.

\section{Pollination system}

Data on pollinators - here defined as animals observed to contact anthers and stigma - were obtained from the same community during the same flowering season (Schenone 1999; Galetto et al., unpublished data). Observations lasting for 20 minutes each were made in two daily periods (morning and afternoon) for at least five days throughout the flowering season of each plant species. Thus, a minimum of 200 minutes more in species with longer flowering periods - of pollinator observations were registered for each plant species. Using the pollinator data, plants were grouped in two conservative categories: pollination-specialists, i.e. plants interacting with only one functional group of pollinators, and pollination-generalists, i.e. plants interacting with at least two functional groups of pollinators. Functional groups were defined according to Fenster et al. (2004).

\section{Data analyses}

Data on pollen size and pistil length were subjected to correlation analyses using Pearson coefficients (Sokal and Rohlf 1995). Values for these floral traits were log-transformed prior to analyses in order to meet normality. To test the 'functional hypothesis', a correlation between pollen size and pistil length including all the species, and partial correlations among pollination-specialist and pollination-generalist species were performed. In addition, we calculated a general correlation among the coefficients of variation $(\mathrm{CVs})$ of those variables, i.e. the respective ratio between the standard deviation and the arithmetic mean.

To test the influence of pollination system on floraltrait variation, we performed a multivariate analysis of variance (MANOVA; Tabachnick and Fidell 1996) with the CVs of pollen size and pistil length between pollination-specialist and -generalist plants. Statistical tests were performed with the SPSS statistical package (SPSS 1999).

\section{Results}

Pollen size ranged from $0.4 \times 10^{3}$ to $5.7 \times 10^{5} \mu \mathrm{m}^{3}$ (Table 1). Oenothera affinis showed the largest pollen grains, Lippia junelliana the smallest. Pistil length ranged from $2.5 \mathrm{~mm}$ (Lantana grisebachii and L. junelliana) to $150 \mathrm{~mm}$ (O. affinis). Considering all species, the CV of pollen size ranged between 0.09 and 0.26 , the $\mathrm{CV}$ of pistil length between 0.04 and 0.17 (Table 1).

A positive correlation between pollen size and pistil length was obtained (Fig. 1); the coefficients of variation

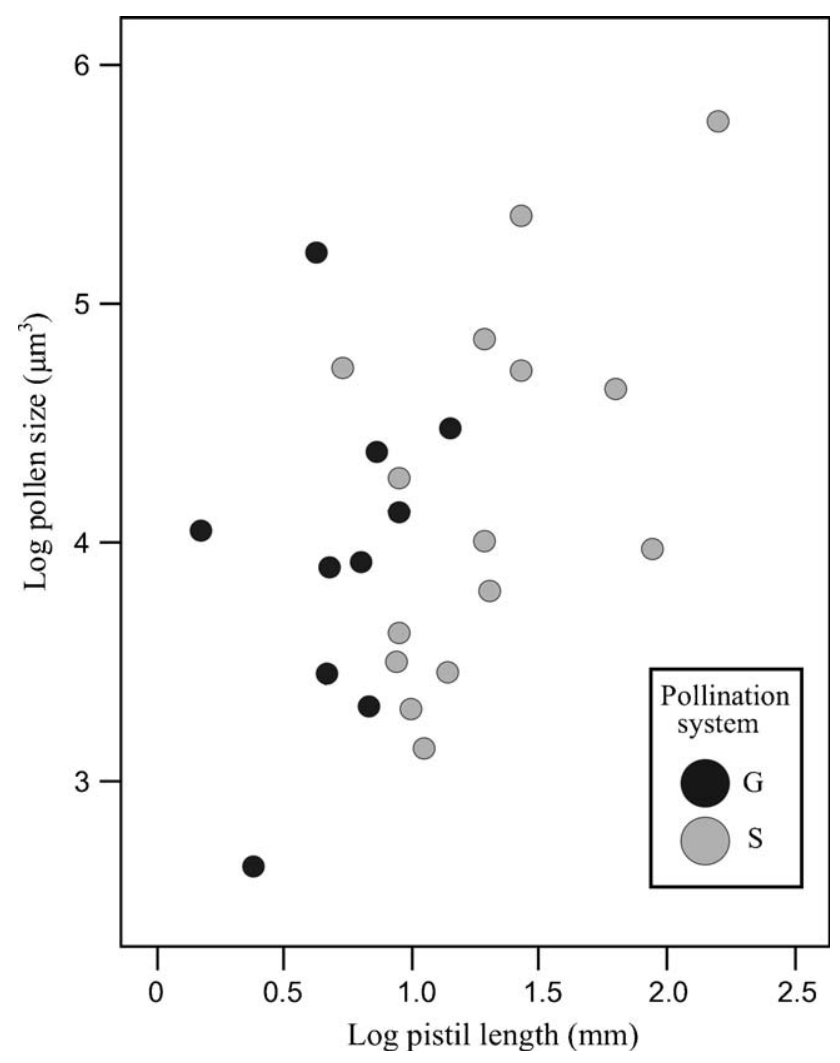

Fig. 1. Correlation between pollen size and pistil length using data from 25 species of a Chaco Serrano community. A positive correlation between these floral traits was found for all species combined $(\mathrm{r}=0.48 ; P=0.02)$. Species are grouped in two pollination systems: $\mathrm{G}=$ pollination generalists $(\mathrm{r}=0.31, P=0.38) ; \mathrm{S}=$ pollination specialists $(\mathrm{r}=0.55$, $P=0.03)$. 
Table 2. Analyses of variance performed for the coefficients of variation $(\mathrm{CV})$ in floral traits of pollination-specialist $(\mathrm{n}=15)$ and -generalist $(\mathrm{n}=10)$ species in a Chaco Serrano Forest community.

\begin{tabular}{|c|c|c|c|c|}
\hline Analysis & $\mathrm{CV}$ of trait & Wilks' $\lambda$ & $F_{[1,25]}$ & $P$ \\
\hline MANOVA (specialist vs. generalist species) & - & 0.854 & 1.87 & 0.18 \\
\hline A posteriori univariate ANOVA & pollen size & - & 2.04 & 0.17 \\
\hline A posteriori univariate ANOVA & pistil length & - & 2.31 & 0.14 \\
\hline
\end{tabular}

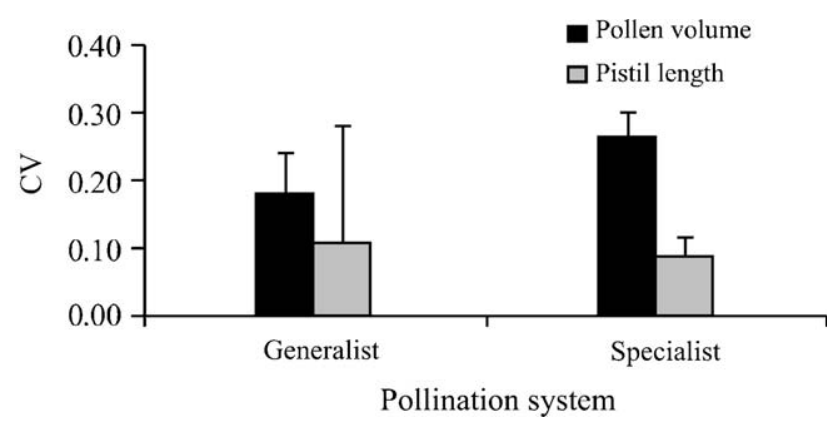

Fig. 2. Mean coefficients of variation (CV) of pollen size and pistil length, respectively, in pollination-specialist and pollination-generalist species from a Chaco Serrano community. Variation in these floral traits did not differ significantly between groups.

of these floral traits were not correlated $(\mathrm{r}=-1.85$, $P=0.38)$.

Data on pollinators are shown in Table 1. From our sampling and observations, 15 of the plant species were classified as pollination specialists, the remaining 10 as pollination generalists. The $\mathrm{CV}$ for pollen size ranged from 0.15 to 0.26 for pollination-specialist plants, from 0.09 to 0.25 for pollination-generalist ones; the $\mathrm{CV}$ for pistil length ranged from 0.04 to 0.15 for pollination specialists, from 0.07 to 0.17 for pollination generalists (Table 1).

When considering only pollination-specialist species, the correlation between pollen size and pistil length was positive $(\mathrm{r}=0.55, P=0.03$; Fig. 1$)$. In contrast, among pollination-generalist species we failed to find a significant correlation ( $\mathrm{r}=0.31, P=0.38$; Fig. 1). MANOVA results showed that pollination-specialist plants did not exhibit less variation in pollen size or pistil length than pollination-generalist plants (Table 2; Fig. 2).

\section{Discussion}

\section{Functional relationship between pollen size and pistil length}

The positive correlation observed between pollen size and pistil length for this group of sympatric species suggests a functional relationship related to the fertilization process. This trend has been reported for many groups of taxonomically related species (e.g. Harder 1998; Roulston et al. 2000; Stroo 2000; Torres 2000; Aguilar et al. 2002; López et al. 2005; but see Cruden and Lyon 1985). In addition, our results based on taxonomically unrelated species support (i) that pollen size and pistil length do not vary independently, as was suggested by Plitmann and Levin (1983), and (ii) the flower-functionality hypothesis, because the CVs of these floral traits were not correlated. Although pollination-generalist plants showed similar trends in the correlation between pollen size and pistil length and in the variability of these traits as did pollinationspecialist plants, we think that the absence of a significant correlation among these floral traits for pollination-generalist species may be due to the sample size being smaller in that group than in pollinationspecialist plants.

What are the possible mechanisms behind these patterns? It has been proposed that pollen size could reflect the storage capacity for certain nutrients that are not synthesized in the style (Roulston et al. 2000). These nutrients affect pollen tube formation and can determine how much a pollen tube can growth (Aguilar et al. 2002), and therefore its ability to reach ovules during the pollination process. Indeed, such a precise adjustment may act as an isolation mechanism (studies reviewed in Torres 2000), which would be 'useful' when stigmas receive pollen from different species. This scenario would be common in communities where the same pollinator assemblage visits many plant species; in that case, a pollinator may carry interspecific pollen loads.

\section{Pollinators and the variation in pollen size and pistil length}

In comparison to the large body of literature on animal-plant interactions, little is known about how pollinators contribute to the variation in floral traits and thus to the maintenance of floral morphologies (e.g. Galen 1999; Johnson and Steiner 2000; Fenster et al. 2004). However, it is conceivable that pollinationgeneralist plants might present more phenotypic variation than pollination specialists. This is a reasonable assumption, because different assemblages of pollinators 
visiting a pollination-generalist plant would show different behaviors, and thus could effect weak selection pressure (Ollerton 1996; but see Waser 1998). Nevertheless, in our results the pollination system was not related to the variability of some floral traits. Several explanations can account for this. Spatio-temporal variation in the composition/abundance of pollinator assemblages is probably one of the most important factors reducing the possibilities of directional selection on floral traits by pollinators (Herrera 1988, 1996; Ollerton 1996; Waser et al. 1996; Stroo 2000; Fenster et al. 2004). Because of this variation, plant species may experience periods of specialization in which floral features may respond to consistent selection from a restricted group of pollinators, and periods of generalization during which selection pressures would be dissipated across a broad spectrum of pollinators (Fenster 1991; Ollerton 1996; Waser 1998). The result of such continuous changes in the pollinator assemblage would determine that directional selection would not occur even in species considered as pollination specialists (Ollerton 1996). Spatio-temporal variability of pollinators has been documented for many species of the Chaco Serrano (Ashworth 2004). An additional explanation is that pollination-generalist plants are as specialized as pollination-specialist plants, which implies that these pollination systems may represent two possible ends of specialization rather than two extremes of a gradient (Torres and Galetto 2002; Gómez and Zamora 2006). If pollination-generalist species represent specialization on many functional groups of pollinators, their flowers will show floral trait variation similar to that in pollinator-specialist species.

Lastly, plant-pollinator networks have been found to show a nested pattern of interactions, implying that generalist species generally interact with generalist and specialist species, whereas specialist species generally interact with generalist species (Bascompte et al. 2003; Ashworth et al. 2004; Vázquez and Aizen 2004, 2006; Jordano et al. 2006). Thus, if pollination-specialist plants generally interact with generalist pollinators they would not display less phenotypic variation than pollination-generalist plants, because generalist pollinators would not depend on these specialist plants only.

\section{Conclusions}

The relationship between pollen size and pistil length among species suggests that the pollination system may be of less importance than flower functionality as concerns selective force. Nevertheless, an experimental approach would be necessary to elucidate the mechanisms beyond the functional relationship between these floral traits. It is not clear how much of this pattern could be attributed to functional or to correlated genetic/ developmental issues, or to a combination of both.

\section{Acknowledgments}

We thank James Cresswell, Carolina Torres, and two anonymous reviewers for useful comments on earlier versions of the manuscript, Mariela Schenone for allowing us to use her unpublished pollinator data, and ANPCyT (Agencia Nacional para la Promoción de la Ciencia y Tecnología), Agencia Córdoba Ciencia, SECYT-UNC (Secretaría de Ciencia y Técnica, Univ. Nac. Córdoba), and CONICET (Consejo Nacional de Investigaciones Científicas y Técnicas) for financial support. L.G. is member of the "Carrera del Investigador" of CONICET; J.A. is holding a $\mathrm{PhD}$ fellowship from the same institution.

\section{References}

Aguilar, R., Bernardello, G., Galetto, L., 2002. Pollen-pistil relationships and pollen size-number trade-off in species of tribe Lycieae (Solanaceae). J. Plant Res. 115, 335-340.

Armbruster, W.S., 1996. Evolution of floral morphology and function: an integrated approach to adaptation, constraint, and compromise in Dalechampia (Euphorbiaceae). In: Lloyd, D., Barrett, S.C.H. (Eds.), Floral Biology. Chapman and Hall, New York, pp. 241-272.

Armbruster, W.S., Martin, P., Kidd, J., Stafford, R., Rogers, D.G., 1995. Reproductive significance of indirect pollentube growth in Dalechampia (Euphorbiaceae). Am. J. Bot. $82,51-56$.

Ashworth, L., 2004. Variabilidad espacio-temporal en el éxito reproductivo de plantas leñosas del "Bosque Chaqueño Serrano". PhD thesis. Facultad de Ciencias Exactas, Físicas y Naturales, Universidad Nacional de Córdoba, Argentina.

Ashworth, L., Aguilar, R., Galetto, L., Aizen, M.A., 2004. Why do pollination-generalist and specialist plant species show similar reproductive susceptibility to habitat fragmentation? J. Ecol. 92, 717-719.

Baker, H.G., Baker, I., 1979. Starch in angiosperm pollen grains and its evolutionary significance. Am. J. Bot. 66, 591-600.

Bascompte, J., Jordano, P., Melián, C.J., Olensen, J.M., 2003. The nested assembly of plant-animal mutualistic networks. Proc. Nat. Acad. Sci. USA 100, 9383-9387.

Bradshaw, H.D., Schemske, D.W., 2003. Allele substitution at a flower color locus produces a pollinator shift in monkeyflowers. Nature 426, 176-178.

Cabrera, A., 1994. Regiones Fitogeográficas Argentinas. ACME, Buenos Aires.

Covas, G., Schnack, B., 1945. El valor taxonómico de la relación "longitud del estilo: tamaño del grano de polen". Darwiniana 7, 80-90.

Cresswell, J.E., 1998. Stabilizing selection and the structural variability of flowers within species. Ann. Bot. 81, 463-473. 
Cruden, R.W., Lyon, D.L., 1985. Correlations among stigma depth, style length, and pollen grain size: do they reflect function or phylogeny? Bot. Gaz. 146, 143-149.

Fenster, C.E., 1991. Selection on floral morphology by hummingbirds. Biotropica 23, 98-101.

Fenster, C.E., Armbruster, W.S., Wilson, P., Dudash, M.R., Thomson, J.D., 2004. Pollination syndrome and floral specialization. Annu. Rev. Ecol. Syst. 35, 375-403.

Galen, C., 1999. Why do flowers vary? The functional ecology of variation in flower size and form within natural plant populations. BioScience 49, 631-640.

Gómez, J.M., Zamora, R., 2006. Ecological factors that promote the evolution of generalization in pollination systems. In: Waser, N.M., Ollerton, J. (Eds.), Plant-pollinator Interactions. From Specialization to Generalization. University of Chicago Press, Chicago, pp. 145-166.

Harder, L.D., 1998. Pollen-size comparisons among animalpollinated angiosperms with different pollination characteristics. Biol. J. Linn. Soc. 64, 513-525.

Herrera, C.M., 1988. Variation in mutualisms: the spatiotemporal mosaic of a pollinator assemblage. Biol. J. Linn. Soc. $35,95-125$.

Herrera, C.M., 1996. Floral traits and plant adaptation to insect pollinators: a devil's advocate approach. In: Lloyd, D.G., Barret, S.C.H. (Eds.), Floral Biology: Studies on Floral Evolution in Animal-pollinated Plants, 1st ed. Chapman and Hall, New York, pp. 65-87.

Herrera, C.M., Cerdá, X., García, M.B., Guitián, J., Medrano, M., Rey, P.J., Sánchez-Lafuente, A.M., 2002. Floral integration, phenotyoic covariance structure and pollinator variation in bumblebee-pollinated Helleborus foetidus. J. Ecol. Biol. 15, 108-121.

Johnson, S.D., Steiner, K.E., 2000. Generalization versus specialization in plant pollination systems. Trends Ecol. Evol. 15, 140-143.

Jordano, P., Bascompte, J., Olesen, J.M., 2006. The ecological consequences of complex topology and nested structure in pollination webs. In: Waser, N.M., Ollerton, J. (Eds.), Plant-pollinator Interactions. From Specialization to Generalization. University of Chicago Press, Chicago, pp. 167-199.

López, H., Galetto, L., Anton, A.M., 2005. Pollen-pistil size correlation and pollen size-number trade-off in species of Argentinian Nyctaginaceae with different pollen reserves. Plant Syst. Evol. 256, 69-73.

Luti, R., Solis, M., Galera, F.M., Muller, N., Berzal, M., Nores, M., Herrera, M., Barrera, J.C., 1979. Vegetación. In: Vázquez, J., Miatello, R., Roque, M. (Eds.), Geografía Física de Córdoba. Boldt, Buenos Aires, pp. 297-367.

Morales, M., 1999. Selección de caracteres florales por polinizadores en especies del bosque serrano (Chaco Serrano). Undergraduate thesis. Facultad de Ciencias Exactas, Físicas y Naturales, Universidad Nacional de Córdoba, Argentina.

Morales, C.L., Galetto, L., 2003. Influence of compatibility system and life form on plant reproductive success. Plant Biol 5, 567-573.

Nilsson, L.A., 1988. The evolution of flowers with deep corolla tubes. Nature 334, 147-149.
Ollerton, J., 1996. Reconciling ecological processes with phylogenetic patterns: the apparent paradox of plantpollinator systems. J. Ecol. 84, 767-769.

Plitmann, U., Levin, D.A., 1983. Pollen-pistil relationships in the Polemoniaceae. Evolution 37, 957-967.

Proctor, M., Yeo, P., Lack, A., 1996. The Natural History of Pollination. Timber Press, Portland.

Roulston, T.H., Cane, J.H., Buchmann, S.L., 2000. What governs protein content of pollen: pollinator preferences, pollen-pistil interactions, or phylogeny? Ecol. Monogr. 70, 617-643.

Sarkissian, T.S., Harder, L.D., 2001. Direct and indirect responses to selection on pollen size in Brassica rapa $\mathrm{L}$. J. Evol. Biol. 14, 456-468.

Schemske, D.W., Bradshaw Jr., H.D., 1999. Pollinator preference and the evolution of floral traits in monkeyflowers (Mimulus). Proc. Nat. Acad. Sci. USA 96, 11910-11915.

Schenone, M., 1999. Estudio de la interacción plantapolinizador en una Comunidad de Bosque Chaqueño Serrano. Undergraduate thesis. Facultad de Ciencias Exactas, Físicas y Naturales, Universidad Nacional de Córdoba, Argentina.

Sokal, R.R., Rohlf, F.J., 1995. Biometry. Freeman, San Francisco.

SPSS, 1999. SPSS for Windows: Base System User's Guide, release 10.0. SPSS Inc., Chicago.

Stroo, A., 2000. Pollen morphological evolution in bat pollinated plants. Plant Syst. Evol. 222, 225-242.

Tabachnick, B., Fidell, L., 1996. Using Multivariate Statistics. Harper Collins, New York.

Temeles, E.J., Kress, W.J., 2003. Adaptation in a planthummingbird association. Science 300, 630-633.

Torres, C., 2000. Pollen size evolution: correlation between pollen size and pistil length in Asteraceae. Sex. Plant Reprod. 12, 365-370.

Torres, C., Galetto, L., 2002. Are nectar-sugar composition and corolla-tube length related to the diversity of insects that visit Asteraceae flowers? Plant Biol 4, 360-366.

Vázquez, D.P., Aizen, M.A., 2004. Asymmetric specialization: a pervasive feature of plant-pollinator interactions. Ecology $85,1251-1257$.

Vázquez, D.P., Aizen, M.A., 2006. Community-wide patterns of specialization in plant-pollinator interactions revealed by null models. In: Waser, N.M., Ollerton, J. (Eds.), Plantpollinator Interactions. From Specialization to Generalization. University of Chicago Press, Chicago, pp. 200-219.

Waser, N.M., 1998. Pollination, angiosperm speciation, and the nature of species boundaries. Oikos 81, 198-201.

Waser, N.M., Chittka, L., Price, M.V., Neal, W.M., Ollerton, J., 1996. Generalization in pollination systems, and why it matters. Ecology 77, 1043-1060.

Williams, E.G., Rouse, J.L., 1990. Relationships of pollen size, pistil length and pollen tube growth rates in Rhododendron and their influence on hybridization. Sex. Plant Reprod. 3, $7-17$.

Yang, C.F., Guo, Y.H., 2004. Pollen size-number trade-off and pollen pistil relationships in Pedicularis (Orobanchaceae). Plant Syst. Evol. 247, 177-185. 